\title{
ANALISIS FILM PEREMPUAN BERKALUNG SORBAN KARYA HANUNG BRAMANTYO MELALUI MODEL SARA MILLS
}

\author{
Andi Yulia Adriani1 ${ }^{*}$, Abdul Muttalib', Naim Irmayani1 \\ IUniversitas Al Asyariah Mandar \\ *Email: aandiyulia27@gmail.com
}

\begin{abstract}
The background in this study is how the application of Sara Mills's discourse analysis model in the film Perempuan Berkalung Sorban. This study aims to determine how the subject-object position and the position of the reader or audience in the film Woman Berkalung Sorban. The position of the subject is the actor who is the narrator (subject). Meanwhile, the position of the object is who is defined and explained by others (the subject). Meanwhile, the position of the reader is how the reader identifies and places himself in the narrative of the text. This type of research uses descriptive qualitative. The data used in this study are dialogue and image scanning in the film Perempuan Berkalung Sorban. The researchers used the theory of feminism as the basis for Sara Mills's discourse analysis that focused on women. The results of this study conclude, that women who stand alone as feminism are described by the main character Annisa as the owner of a Kyai child from the Salafiah Putri AlHuda Islamic boarding school and his mother and wife. The women depicted in this film are positioned as intelligent, beautiful, and independent human beings, despite all forms of oppression in the name of gender, and are able to show their dignity and dignity as women. In this film, Berkalung Sorban proves that women are not weak but that men and women are created with the same potential abilities or are usually said with gender equality shown in cut scenes and dialogues in the film.
\end{abstract}

Keywords: subjects, objects, readers, feminism, women berkalung turban

\section{PENDAHULUAN}

Analisis wacana menurut Labov (Darma, 2009:17) merupakan sebuah penggambaran secara rasional mengenai hubungan runtutan yang berada dalam kesatuan yang teratur, sehingga nampak jelas hubungan unsur-unsur di dalamnya, hubungan antar unsur di luar kesatuan tersebut mau pun koherensinya.

Menurut Eriyanto (2011:4), ada tiga pandangan mengenai bahasa dalam analisis wacana. Pertama kaum empiris, bahasa dilihat sebagai jembatan antara manusia dengan objek di luar dirinya. Pengalaman-pengalaman manusia dianggap 
dapat secara langsung diekspresikan melalui penggunaan bahasa tanpa ada kendala atau distorsi, sejauh ia dinyatakan dengan memakai pernyataan yang logis.Dalam kaitannya dengan analisis wacana, konsekuensi logis dari pemahaman ini adalah orang tidak perlu mengetahui makna-makna subjektif atau nilai yang mendasari pernyataannya. Kesimpulan dari analisis wacana adalah suatu cara atau metode untuk mengkaji isi pesan komunikasi yang ada di teks, baik secara bahasa ataupun penulisan.

Analisis wacana memiliki tiga pandangan dari segi bahasa.Pandangan pertama diwakili oleh kaum positivism- empiris. Oleh penganut aliran ini, bahasa dilihat sebagai jembatan antara manusia dengan objek diluar dirinya. Pengalaman-pengalaman manusia dapat diekspresikan secara langsung melalui penggunaan bahasa tanpa ada kendala atau distorsi. Salah satu cirri pemikiran ini adalah pemisah antara pemikiran dan realitas. Pandangan ini terfokus pada kebenaran tata bahasa sintaksis. Pandangan kedua yaitu konstruktivisme, pandangan ini menolak pemikiran positivism- empiris yang memisahkan subjek sebagi control terhadap maksud-maksud tertentu dalam setiap wacana.

Para ahli telah membuat penjelasan tentang wacana secara beragam, demikian pula halnya apabila mengklafikasikan sebuag wacana. Berdasarkan bentuknya atau jenisnya, wacana dibedakan menjadi wacana deskriptif, naratif, ekspositoris, persuasif dan argumentatif (Darma, 2014:27). Wacana berdasarkan media penyampaiannya yakni, wacana tulis atau written discourse adalah wacana yang disampaikan secara tertulis, melalui media tulis dan wacana lisan atau speaken discourse adalah wacana yang disampaikan secara lisan, melihat media lisan. Adapun wacana berdasarkan jumlah penutur yaitu, wacana dialog dan monolog

Wacana Berdasarkan Sifatnya yaitu, wacana fiksi adalah wacana yang bentuk dan isinya berorientasi pada imajinasi umumnya, penampilan dan rasa bahasanya dikemas secara literer atau estetis (indah). Wacana nonfiksi disebut juga wacana ilmiah Bahasa yang digunakan bersifat denotative, lugas dan jelas. Aspek estetika bukan lagi menjadi tujuan utama. Beberapa contoh wacana nonfiksi, yaitu laporan penelitian buku materi perkuliahan, petunjuk mengoperasikan pesawat terbang dan sebagainya (Mulyana, 2005 : 54).

Analisis wacana model Sara Mills lebih memusatkan perhatiannya pada wacana tentang perempuan. Bagaimana perempuan ditampilkan dalam teks, novel, gambar, foto ataupun berita. Pendekatan wacana ini sering disebut sebagai perspektif Sara Mills.Titik perhatian dari perspektif wacana feminisme adalah menunjukkan bagaimana teks bisa dalam menampilkan perempuan. Perempuan cenderung ditampilkan dalam teks sebagai pihak yang salah, marjinal dibandingkan dengan pihak laki-laki. Gagasan Sara Mills agak berbeda dengan model critical linguistics. Jika critical linguistics memusatkan perhatian pada struktur kebahasaan dan bagaimana pengaruhnya dalam pemaknaan khalayak, 
maka Sara Mills lebih melihat pada bagaimana posisi-posisi aktor ditampilkan dalam teks.

Posisi ini dalam arti siapa yang menjadi subjek dalam penceritaan dan siapa yang dijadikan objek penceritaan. Selain itu, Sara Mills juga memusatkan perhatian pada bagaimana dan penulis ditampilkan dalam teks. Bagaimana pembaca mengidentifikasi dan menempatkan dirinya dalam penceritaan didapatkan bagaimana struktur dari adegan yang ditampilkan dan bagaimana makna diberlakukan dalam adegan secara keseluruhan. Sementara untuk posisi pembaca dalam penelitian ini diasumsikan sebagai penonton. Sehubungan dengan penelitian yang akan dilakukan adalah penelitian terhadap tayangan televisi, maka dari itu yang akan dilihat adalah bagaimana posisi aktor ditampilkan dalam sebuah adegan.

Perfilman lebih banyak mengangkat isu feminisme karena memiliki nilai jual yang mampu menarik minat khalayak untuk mengkonsumsi film tersebut. Dengan kata lain, perfilman di berbagai dunia masih menggunakan ideologi patriarki. Konsep feminisme dalam berbagai kajian umum yang banyak diikuti oleh kaum wanita terbagi atas dua, yakni: Pertama, kaum wanita dunia kesatu beranggapan bahwa kebebasan wanita harus dikaitkan dengan kehidupan seksualitas yang selalu menjadi isu diskriminasi gender yang terjadi di berbagai belahan dunia. Kedua, kaum wanita dunia ketiga, yang lebih tertarik untuk memperjuangkan hak mereka atas isu politik dan ekonomi dan bukan seksualitas (Tong, 2009: 22).

Analisis wacana dimaksudkan sebagai suatu analisis untuk membongkar maksud-maksud dan makna tertentu. Wacana adalah suatu upaya pengungkapan maksud tersembunyi dari sang subjek yang mengemukakan suatu pernyataan. Proses analisis wacana memungkinkan kita untuk menguji cara di mana pencapaian tujuan dapat dimengerti melalui pesan-pesan. Analisis wacana adalah analisis yang berhubungan dengan studi mengenai bahasa atau pemakaian bahasa.

Seperti yang dinyatakan oleh Sara Mills bahwa analisis wacana dapat dilihat sebagai reaksi yang lebih pada bentuk linguistik dimana fokus pada unitunit yang konstituen dan struktur kalimat dan tidak fokus pada kalimat itu sendiri dengan sebuah analisis bahasa yang digunakan ada beberapa pandangan dalam analisis wacana (Eriyanto, 2001: 34).

Perempuan sesungguhnya tidak dapat menyamai kedudukan lelaki dalam posisi tertinggi.Karena perempuan masih memiliki kehidupan domestik seperti ingin memiliki anak dan kehidupan berumahtangga lainnya yang menurut anggapan para feminis bahwa perempuan tidak bisa memiliki pemikiran yang rasional.

Salah satu faktor penghambat perempuan tidak memiliki pemikiran yang rasional karena perempuan tidak dapat memasuki sektor publik. Permasalahan 
utamanya adalah permasalahan biologis. Perempuan ditakdirkan sebagai makhluk yang memiliki hak untuk reproduksi. Dengan demikian perempuan tidak bisa menyamai kedudukan lelaki, sehingga lelaki tetap dalam kedudukan tertinggi. Film ini menunjukkan bagaimana perempuan termarginalkan karena profesinya sebagai penembak jitu didominasi oleh lelaki ditunjukkan dalam potongan adegan dan dialog dalam film tersebut.Inilah yang kemudian menjadi dasar sebuah penelitan dengan menggunakan metode analisis wacana milik Sara Milss, dalam film Perempuan Berkalung Sorban, sehingga fokus pada penelitian ini adalah untuk mengetahui penerapan model Analisis Wacana Sarah Milss pada film Perempuan Berkalung Sorban.

\section{METODE PENELITIAN}

Penelitian ini merupakan penelitian deskriptif kualitatif yang didasarkan pada data alamiah berupa kata- kata dalam mendeskripsikan objek yang diteliti. Data dalam penelitian ini adalah sebuah film (audio visual) dan sumber data berupa rangkaian gambar (scene) dan dialog dari film yang berjudul Perempuan Berkalung Sorban karya Hanung Bramantyo yang akan di teliti oleh peneliti melalui analisis wacana model Sarah Milss. Fokus pada penelitian ini adalah penerapan model analisis wacana Sarah Milss, bagaimana posisi subjek, objek dan pembaca dalam mengambarkan perempuan pada film Perempuan Berkalung Sorban berupa potongan adegan (scene) dan dialog.

Instrumen penelitian dalam penelitian ini adalah peneliti sendiri atau human instrument yang berperan sebagai (1) perencana, (2) pelaksana, (3) pengambil data, (4) penganalisis, (5) penafsir dan sekaliguspelapor hasil penelitian. Pengetahuan dan wawasan kebahasaan peneliti khususnya teori tentang tindak tutur menjadi kunci pokok dalam keberhasilan penelitian. Teknik pengumpulan data dalam penelitian ini adalah, teknik simak dan mencatat. Teknik Simak adalah teknik pengumpulan data dengan menyimak penggunaan bahasa. Teknik catat adalah teknik atau cara yang digunakan untuk mencatat data-data yang ditemukan ke dalam nota pencatat data. Setelah data terkumpul data dianalisis dengan menggunakan metode deskriptif. Adapun penggunaan tahapan analisis data dalam penelitian ini adalah dengan meninjau kembali beberapa penelitian terdahulu tentang film yang menggunakan model Sarah Milss sebagai proses interpretasi. Secara kongkret, analisis data film ini dengan beberapa tahapan sebagai berikut.

1. Menonton dan Membaca Film

Suatu makna dalam teks dapat timbul ketika makna tersebut dibaca. Melalui proses pengulangan baca, maka penafsir akan semakin memahami konteks cerita yang didapat, sehingga memperoleh tahapan pemahaman awal. Hal ini pula 
dinyatakan oleh Jaques Derrida bahwa teori interpretasi pada dasarnya adalah teori membaca, yang pada akhirnya juga adalah teori tentang teks. Pemahaman seseorang ialah bergantung pada bagaimana ia membaca teks (Sumaryono, 2009: 133). Memahami makna keseluruhan cerita dengan pendekatan model Sarah Milss yang di fokuskan pada bagaimana posisi subjek, objek dan pembaca dalam mengambarkan perempuan pada film Perempuan Berkalung Sorban berupa potongan adegan (scene) dan dialog. (1) Mendaftar wacana-wacana yang sudah teridentifikasi dalam film sesuai dengan fokus permasalahan berdasarkan poin 2 . (2) Apabila belum mendapatkan pemahaman secara optimal, maka proses dapat diulangi sampai dirasa cukup. (3) Menyusun kesimpulan pemahaman.

\section{HASIL DAN PEMBAHASAN}

Data-data yang diperoleh dan dibahas merupakan analisis wacana model Sara Milss pada film Perempuan Berkalung Sorban karya Hanung Bramantyo. Model analisis wacana Sara Mills ini terdapat dua konsep utama yang akan dilihat dalam komponen film Perempuan Berkalung Sorban yaitu posisi subjek-objek dan posisi pembaca atau penonton. Dapat dilihat pada table berikut :

Tabel 1. Hasil analisis wacana model sara milss

\begin{tabular}{lc}
\hline Analisis wacana model Sara Milss & Jumlah data yang ditemukan \\
\hline Posisi Subjek & 06 data \\
Posisi Objek & 04 data \\
Posisi Pembaca atau Penonton & 0 data \\
\hline Jumlah & 10 data \\
\hline
\end{tabular}

Hasil penelitian ini menunjukkan bahwa pada film Perempuan Berkalung Sorban karya Hanung Bramantyo ditemukan 10 data berdasarkan hasil analisis wacana melalui model Sara Milss. Untuk posisi pembaca atau penonton di temukan nol data karena posisi pembaca atau penonton disini merupakan peneliti sendiri yang akan mendesripsikan atau menyimpulkan film tersebut.

Temuan data pada posisi subjek terbagi menjadi empat bagian, yakni posisi subjek dalam perlawanan untuk menjadi pemimpin, perlawanan menempuh pendidikan formal, dan perlawanan terhadap tindakan KDRT (Kekerasan dalam Rumah Tangga) :

a) Subjek dalam Perlawanan Untuk Menjadi Pemimpin

Pada scane 14 yaitu scane pemilihan ketua kelas di kelas Annisa. Ketua kelas dipilih dengan cara voting atau suara terbanyak. Ada dua calon ketua kelas, yaitu Farid dan Annisa. Annisa tidak dapat menjadi ketua kelas walaupun dia yang memenangkan voting itu karena dalam Islam perempuan tidak boleh jadi pemimpin. Perlawanan Annisa ditunjjukan dengan 
meninggalkan kelas karena tidak setuju dengan keputusan dari Pak Guru. Keyakinan bahwa laki- laki harus "memimpin" kaum perempuan tersebut sesungguhnya tidaklah menjadi masalah sepanjang "kepemimpinannya" bersifat adil dan tidak menindas. Namun persoalan lain yang timbul adalah justru kepercayaan tersebut membawa pada keyakinan, bahwa kaum perempuan adalah "soburninasi" dari kaum laki- laki, meskipun secara objektif misalnya Ia lebih mampu, lebih pandai, dan lebih layak.

b) Subjek dalam Perlawanan Menempuh Pendidikan Formal

Scane 31 yaitu perlawanan Annisa untuk mendapatkan pendidikan digambarkan dengan mendapatkan beasiswa kemudian minta ijin Kyai Hanan untuk melanjutkan kuliah di Jogja dengan beasiswa tersebut. Keluarga patriarki semua keputusan ada ditangan bapak sebagai kepala keluarga. Begitu pula dalam kesempatan memperoleh pendidikan antara lakilaki dengan perempuan, semuanya ditentukan oleh kepala keluarga. Annisa tidak diijinkan kuliah di Jogja dengan alasan perempuan tidak boleh keluar tanpa muhrim. Sedangkan kedua kakaknya Wildan dan Reza diharuskan sekolah tinggi hingga ke Mekkah dan Madinah walaupun sampai menjual tanah dan meminjam uang kepada orang lain. Perempuan tidak perlu memperoleh pendidikan tinggi karena pada akhirnya hanya akan mengurus rumah tanggga.

Sedangkan laki- laki harus memperolah pendidikan tinggi karena dianggap mempunyai tanggung jawab yang lebih besar. Begitulah pendapat Kyai Hanan sebagai kepala keluarga patriarki. Jelas sekali bahwa Kyai Hanan melakukan perbedaan perlakuan terhadap anak laki- laki dan perempuannya. Salah satunya dengan menomordukan pendidikan untuk anak perempuannya, tidak memerlukan pendidikan tinggi karena gunanya perempuan setelah menikah mengurus suami dan anak.

c) Subjek dalam Perlawanan KDRT (Kekerasan dalam Rumah Tangga)

Scane 36 Annisa digambarkan kurus dan matanya cekung. Dia tampak tertekan dan kelelahan. Begitupula dengan Samsudin yang tampak sangat acak- acakan karena sering mabuk- mabukan. Annisa tertekan dengan kelakuan suaminya. Dari dialog Annisa dan Samsuddin dapat diketahui bahwa Samsudin jarang pulang melaingkan keluyuran dan mabuk- mabukan. Annisa masih belum diperbolehkan kuliah. Perlawanannya ditunjukkan dengan menyatakan keinginannya untuk kuliah dan bahwa dia tidak ingin hiduo dirumah sepanjang hari untuk mengerjakan pekerjaan rumah. Samsudin tamak kesal dengan keinginan Annisa kuliah, kemudian marah dan mendorong Annisa ke dinding hingga terjadi kekerasan dalam rumah tangga baik secara fisik maupun psikis.

Banyak sekali kekerasan pada perempuan yang ditimbulkan karena adanya stereotipe gender. Pemerkosaan yang merupakan salah satu bentuk 
violence yang sering kali terjadi, sebenarnya bukan disebabkan karena unsur kecantikan, melainkan karena kekuasaan dan stereotipe gender yang dilekatkan pada kaum perempuan. Bahwa karena perbedaan gender dan sosialisasi gender yang amat lama, sehingga menimbulkan kaum perempuan secara fisik lemah dan kaum laki- laki umumnya lebih kuat. Hal itu tidak menimbulkan masalah sepanjang anggapan lemahnya perempuan tersebut tidak mendorong laki-laki boleh dan seenaknya memukul dan memperkosa perempuan hal ini digambarkan pada scane 42 .

Scane 42 terjadi kekerasan dalam rumah tangga dalam hal hubungan seksual. Di dalam perkawinan juga masih terdapat istilah pemerkosaan. Artinya pemerkosan terjadi jika seseorang untuk mendapatkan pelayanan seksual dilakukan secara paksa tanpa mendapat kerelaan yang bersangkutan. Di scane 45 masih terjadi lagi pemerkosaan Samsudin terhadap Annisa, saat Annisa sedang merintih sakit perut karena sedang haid pertama, samsudin tidak mau tau. Ia tetap memaksa Annisa melayaninya. Di scane ini terjadi lagi kekerasan fisik dan psikis. Karena tidak hanya serangan- serangan terhadap psikis yaitu dengan melontarkan kata- kata kasar. Ketidak relaan dalam melakukan hubungan seksual dapat disebabkan oleh beberapa faktor, misalnya ketakutan, malu, keterpaksaan dan segi ekonomi, sosial maupun kultural sehingga tidak mempunyai pilihan lain. Annisa tidak ingin tubuhnya dikuasai oleh Samsudin, dia berusaha menolak paksaan Samsudin tapi tidak bisa. Kekerasan pada perempuan disebabkan oleh ketidaksetaraan kekuatan yang ada dalam masyarakat.

Adanya strotipe gender yang menganggap perumpuan itu lemah, sehingga mendorong laki- laki untuk bertindak seenaknya pada perempuan. Ketika mendapatkan kesempatan untuk beranjak dari kasur, Annisa lari dan melakukan perlawanan dengan mengambil senjata tajam untuk mengancam Samsudin digambarkan pada scane 46. Annisa sudah muak dan lelah atas perlakuan Samsudin terhadapnya. Kehidupan berumah tangga hubungan seksual seharusnya menjadi sesuatu yang baik, Namun karena selalu dipaksakan dapat menimbulkan efek buruk seperti keluarga yang tidak harmonis dan dapat memunculkan trauma.

Temuan data pada posisi objek Film Perempuan Berkalung Sorban, Annisa sebagai subjek pencerita mengambarkan orang- orang di pesantrennya dapat dilihat

a) Kyai Hanan Menghukum Annisa

Scane 16, Kyai Hanan marah dan menghukum Annisa, karena Kyai Hanan membenarkan bahwa laki- laki yang pantas menjadi pemimpin bukan perempuan walaupun Annisa memenangkan voting untuk menjadi ketua kelas. Dia mendapatkan hukuman. Karena sistem patriarki yang kental membuat kepala rumah tangga mempunyai kekuasaan dan mendorongnya untuk mengambil tindakan menghukum dengan hukuman fisik. Jadi kekerasan 
terhadap anak (child abuse) dapat terjadi karena seorang bapak merasa berkuasa memberikan hukuman kepada anaknya.

b) Khudori mengajarkkan kesetaraan gender kepada satriwati

Scane 120 Khudori mengajarkan ilmu mengenai kesetaraan gender kepada santriwati dalam pesantren tersebut. Tentang teori nature dan nurture, teori nature menganggap bahwa perbedaan laki-laki dan perempuan bersifat kodrati, (nature). Sedangkan teori nurture beranggapan perbedaan relasi gender antara laki-laki dan perempuan tidak ditentukan oleh faktor biologis, melainkan oleh konstruksi masyarakat. Baik laki-laki maupun perempuan itu memiliki kesempatan dan ruang yang sama untuk berkreasi, mengembangkan diri sampai dengan belajar. Semua ajaran yang diajarkan Khudori mengenai kesetaraan ini sangat bertentangan dengan pesantren pada waktu itu.

c) Pendirian Perpustakaan Modern Ditentang Oleh Pihak Pesantren

Scane 115, Keinginan Annisa ditolak mentah-mentah oleh Reza, kakak Annisa. Reza takut jika perempuan membaca buku-buku modern, mereka akan keluar dari kodratnya. Kodrat perempuan dalam konsepsi Reza adalah mengurus rumah tangga dan melayani suami. Sedangkan pengertian kodrat adalah sifat nature manusia, yaitu segala sesuatu pemberian Tuhan, seperti perempuan hamil, melahirkan dan menyusui, sedangkan laki-laki tidak. Yang dimaksud Reza kodrat perempuan mengurus rumah tangga dan melayani suami merupakan sifat nurture manusia. Yaitu bentukan dari sosial budaya masyarakat sendiri, bukan kodrati.

Scane 136, Semua pihak pesantren tidak menyetujui ide Annisa. Buku-buku modern dianggap dapat merusak akhlak dan akidah para santri. Hanya kitab suci bacaan yang diperbolehkan, buku-buku modern tidak diperlukan.

Pembaca atau penonton ditempatkan bukan hanya sebagai pihak yang menerima teks, tetapi juga pihak yang ikut melakukan transaksi sebagaimana akan terlihat dalam teks. Penempatan posisi pembaca atau penonton ini biasanya dihubungkan dengan bagaimana penyapaan atau penyebutan dilakukan dalam sebuah teks. Pada film Perempuan Berkalung Sorban, Annisa dikisahkan dengan sudut pandang orang pertama yang menceritakan kisah hidupnya di Pesantren Putri Al Huda Jombang, Jawa Timur. Maka, pembaca akan mengidentifikasi atau mensejajarkan dirinya dengan Annisa yang adalah karakter utama dalam teks.

Penggambaran karakter tokoh Annisa yang meski mendapat banyak perlakuan diskriminasi gender, Ia tetap kuat dan tegar, secara tidak sadar menempatkan pembaca pada karakter Annisa dan turut merasakan kesedihankesedihan yang dialaminya. Pengisahan tokoh Annisa ini juga, penonton dalam 
hal ini sebagai peneliti diajak untuk menyelami kesedihan-kesedihan yang ia alami. Cara pengisahan tersebut membuat peneliti turut merasakan naik-turunnya emosi Annisa mengahadapi segalanya. Kesulitan Annisa untuk menjadi pemimpin saat Ia masih duduk di bangku madrasah dengan alasan perempuan tidak boleh jadi pimpinan dalam Islam dan melajutkan pendidikanya keluar kota ditentang oleh ayahnya sebab perempuan kodratnya hanya megurus suami dan keluarga. Penggambaran kesedihan dan perlawanan Annisa menampilkan perasaan bahwa dirinya sangat dibatasi untuk maju dan berkembang. Hal tersebut membuat khalayak seakan diajak untuk bersimpati dengan merasakan deskriminasi yang di alami Annisa sebagai perempuan.

Film Perempuan Berkalung Sorban, peneliti mengajak membaca atau penonton untuk merasakan dikekang dan diperlakukan kasar oleh suami dan ayahnya sendiri bahkan dalam potongan adegan dengan kalimat yang menggambarkan kejadian Annisa siseret oleh ayahnya karena Annisa tidak diperlakukan adil oleh pak guru. Tidak sampai disitu saja pembaca atau penonton masih sangat dibuat emosional dan empati setelah adegan Annisa dijodohkan dengan Samsudin dan menikah degannya Annisa masih terus megalami deskriminasi tanpa henti serta saat Annisa ingin mendirikan perpustakaan modern dengan tujuan agar para satri punya wadah untuk maju dan berkembang, pendapat Annisa masih saja tidak diterima oleh pihak pesantren dengan alasan dapat merusak akhalak dan akidah para satri

Di akhir adegan film Perempuan Berkalung Sorban, terlepas dari semua deskriminasi yang di alami Annisa. Annisa mampu bangkit dan pantang meyerah ia terus berjuang demi para satri di pesantrennya Ia meraskan betul bagaimana hidup dipesantren yang kolot dan kaku. Annisa berusaha mengubah itu semua dengan mendirikan pesantren modern yang pada akhirnya di setujui oleh pihak pesantren. Dalam hal ini pembaca atau penonton akan meraskan sesansi perjuangan Annisa yang sangat luar biasa untuk kaumnya di pesantren agar mereka bisa bebas maju dan berkembang tanpa ada lagi kekangan. Dengan alur cerita campuran sosok Annisa menjadi subjek penceritaan yang mendominasi dalam film Perempuan Berkalung Sorban.

\section{SIMPULAN}

Berdasarkan hasil penelitian di atas, maka kesimpulan dari penelitian Analisis Film Perempuan Berkalung Sorban Karya Hanung Bramantyo Melalui Model Sara Mills, yaitu sebagai berikut:

1. Posisi subjek atau pencerita yang digambarkan dalam film Perempuan Berkalung Sorban adalah Annisa yang berperan sebagai tokoh utama. Semua peritiwa yang terjadi dalam film adalah penggambaran dari keterangan 
pelaku yang dalam hal ini adalah perempuan dalam deskriminasi genre. Perempuan yang menjadi subjek ini menceritakan kejadian- kejadian yang menimpa diri, keluarga, dan kaumnya dipesantren. Meski yang diceritan tentang bentuk deskriminasi gender, tetapi di dalam film tersebut terdapat kata- kata yang mengarahkan pada perjuangan seorang perempuan untuk meraih kebebasan.

2. Posisi objek dalam film Perempuan Berkalung Sorban adalah sosok Kyai Ali, Khudori, Kyai Hanan, Reza, Wildan, dan orang- orang dipesantren. Karena menjadi objek pencerita mereka mampu menampilkan dirinya sendiri.

3. Posisi pembaca atau penonton merupakan peneliti sendiri. Peneliti merasakan di rasakan Annisa dengan berbagai macam tidakan deskriminasi gender yang Ia terima, namun Ia bangkit dan memperjuangkan hak- hak prempuan.

\section{SARAN}

Berdasarkan hasil penelitian di atas, maka kesimpulan dari penelitian Analisis Film Perempuan Berkalung Sorban Karya Hanung Bramantyo Melalui Model Sara Mills, maka peneliti dapat memberikan beberapa saran sebagaiberikut:

1. Kepada para pembaca yang berminat melakukan penelitian khusunya pada kajian film, hendaknya mampu mengembangkan penelitiandengan metodologi yang sesuai dengan kajian film agar lebih kritis dan lebih banyak mencari referensi.

2. Kepada pembuat film, disarankan untuk mengurangiadegan-adegan kekerasan khususnya pada perempuan. Semoga selalu memberikan pesan moral yang dapat mendidik dan jadi inspirasi para penikmat film.

3. Kepada penikmat film, disarankan agar menjadi penikmat film cerdas dan selektif dalam menonton film. Pilihlah film yang memiliki pesan moral yang baik.

\section{DAFTAR PUSTAKA}

Darma, Yoce Aliah. 2009. Analisis Wacana Kritis. Bandung : Yrama Widya.

Darma, Yoce Aliyah. 2014. Analisis Wacana Kritis Dalam Multiperspektif. Bandung: PT. Refika Aditama.

Depdikbud. 2005. Kamus Besar Bahasa Indonesia Edisi III. Jakarta: Balai Pustaka.

Eriyanto. 2001. Analisis Wacana Pengantar Analisis Teks Media. Yogyakarta: LKiS Pelangi Aksara.

Eriyanto.2006. Analisis Wacana Pengantar Analisis Teks Media. Yogyakarta: LKiS Pelangi Aksara. 
Mulyana. 2005. Kajian Wacana: Teori, Metode, dan Aplikasi Prinsip Analisis Wacana. Yogyakarta: Tiara Wacana.

Tong, Rosmarie Putnam. 2009. Feminist Thought. California : Westview Press. Wiryodijoyo, Sumarjono. 2010. Membaca: Strategi Pengantar dan Tekniknya. Jakarta: P2LPTK. 